\title{
Peran Komitmen Organisasional Sebagai Mediator Pengaruh Keadilan Prosedural dan Kepuasan Kerja Terhadap Organizational Citizenship Behaviour Karyawan PT Patrari Jaya Utama
}

\author{
Sumijan \\ Universitas Islam Indonesia \\ *pagak12@gmail.com
}

\begin{abstract}
The purpose of this study was to examine and analyze the effect of Procedural Justice and Job Satisfaction on Organizational Commitment; to examine and analyze the effect of Procedural Justice and Job Satisfaction on Organizational Citizenship Behavior; to test and analyze the effect of Organizational Commitment on Organizational Citizenship Behavior; to test and analyze which influence is greater between the direct influence of Procedural Justice and Job Satisfaction on Organizational Citizenship Behavior through Organizational Commitment with or indirect influence. In this study, the research sample will be the population of all employees of PT Patrari Jaya Utama, so the technique used in this study is a census of 65 employees. The analysis tool used is Multiple Linear Regression Analysis and Path Analysis. The results showed that there was a significant influence between Procedural Justice and Job Satisfaction on Organizational Commitment: There was a significant influence between Procedural Justice on Organizational Citizenship Behavior; There is no influence between job satisfaction on Organizational Citizenship Behavior; There is a significant influence between Organizational Commitment to Organizational Citizenship Behavior.
\end{abstract}

Keywords: Organizational Commitment, Procedural Justice, Job Satisfaction and Organizational Citizenship Behavior

\section{Pendahuluan}

Widyaningrum (2010) menuturkan bahwa untuk membangun komitmen karyawan dan Organizational Citizenship Behavior (OCB) adalah dengan terbentuknya kepuasan kerja yang dirasakan karyawan, selanjutnya peranan penting pembentuk kepuasan kerja yaitu menciptakan perlakuan yang adil pada diri karyawan. Sehingga disebutkan pula oleh Widyaningrum bahwa tingkat keadilan merupakan gambaran situasional secara sosial di mana ketika norma mengenai hak dan kewajiban telah terpenuhi (Widyaningrum, 2010). Karyawan akan merasakan adil atau tidak jika dilihat dari tiga indikator, antara lain keadilan distributif, keadilan prosedural, serta keadilan interaksional. Keadilan tersebut lah merupakan penentu penting terbentuknya kepuasan kerja. Selain itu terdapat satu anteseden guna meningkatkan tingkat komitmen karyawan terhadap organisasi serta perilaku kewargaan karyawan atau istilah nya adalah OCB sehingga akan terbentuknya rasa puas terhadap perkerjaannya. Poin kunci untuk membentuk tingkat komitmen karyawan dan OCB melalui terbentuknya kepuasan kerja. Selanjutnya peran terpenting dari pembentuk sikap puas karyawan yaitu terbentuknya rasa adil yang diterima karyawan. Umumnya tingkat keadilan 


\section{Sumijan}

digambarkan pada kondisi sosial ketika aturan mengenai hak dan kewajiban karyawan sudah terpenuhi. Keadilan merupakan nilai-nilai universal dan global serta merupakan hak yang melekat yang dirasakan. Ketika perusahaan memperlakukan secara adil dan menerapkan keadilan prosedural maka karyawan akan merasa lebih puas serta mereka akan menunjukkan perilaku di luar deskripsi pekerjaannya, tingkat remunerasi serta sistem penghargaan secara formal, dan tentunya akan terciptanya OCB pada perusahaan. Mengacu pada teori pertukaran sosial disebutkan bahwa hubungan yang terjadi antara pegawai dan organisasi menjadi bentuk pertukaran sosial sehingga tidak lagi mendasarkan pada aspek pertukaran ekonomis. Pembentuk aspek pertukaran sosial adanya timbul rasa kepercayaan pada organisasi serta munculnya feedback antar kedua pihak. Para karyawan yang merasakan adanya perlakuan adil dari perusahaan akan semestinya memberikan bentuk balas imbal jasa pada sikap dan perilaku rasa kewargaan atau OCB yang positif sehingga terdukungnya tujuan organisasi yaitu sikap komit karyawan. Dengan memberikan perlakuan yang adil pada karyawan, sebuah organisasi maka mendapatkan benefit yang saling menguntungkan dan saling mendukung keefektifan sebuah organisasi antara lain dalam bentuk peningkatan kuantitas, kualitas kerja, produktivitas dan kualitas capaian hasil yang diperoleh.

Hasil riset-riset terdahulu membuktikan adanya keterkaitan antara tingkat keadilan organisasi, komitmen organisasional, dan OCB pada peneliti sebelumnya seperti penelitian yang dilakukan Allameh, et al 2011; Alotaibi, 2001; survey lanjutan Damayanti dan Suhariadi, 2003). Dukungan tersebut menjadi landasan teoritik social exchange mengenai adanya kaitan antara keadilan organisasi pada sikap komit karyawan dan perilaku kewargaan atau OCB. Selain itu tambahan Moorman (2003), bahwa tingkat komitmen dan OCB dijelaskan pada teoritik perspektif identitas sosial (social identity) di mana merupakan dasar teori relasional berdasarkan kekuasaan. Penjelasannya adalah dilihat secara teori identitas sosial, kesediaan karyawan akan menunjukkan suatu perilaku akan mendukung visi perusahaan atau visi atas sebab adanya anteseden berupa identifikasi organisasi. Sedangkan Scholl (1981) melakukan identifikasi aspek inti sebuah komitmen afektif karyawan pada organisasi yang akan menjadi cerminan bentuk ikatan secara psikologis karyawan dengan organisasi. Mengacu pada teori pertukaran sosial serta teori identitas sosial maka tingkat keadilan organisasi (keadilan distributif, keadilan prosedural, dan keadilan interaksional) yang dirasakan karyawan akan berpengaruh searah dengan tingkat kepuasan kerja, komitmen karyawan pada organisasi dan juga akan meningkatkan OCB.

Mengacu pada penjelasan tersebut maka dapat diajukan pertanyaan dalam penelitian adalah sebagai berikut Apakah Keadilan Prosedural berpengaruh terhadap Komitmen Organisasional?; Apakah Kepuasan Kerja berpengaruh terhadap Komitmen Organisasional?; Apakah Keadilan Prosedural berpengaruh terhadap Organizational Citizenship Behaviour?; Apakah Kepuasan Kerja berpengaruh terhadap Organizational Citizenship Behaviour?; Apakah Komitmen Organisasional berpengaruh terhadap Organizational Citizenship Behaviour? ; Lebih besar mana pengaruh secara langsung Keadilan Prosedural terhadap Organizational Citizenship Behaviour melalui Komitmen Organisasional dengan pengaruh tidak langsung Keadilan Prosedural terhadap Organizational Citizenship Behaviour melalui Komitmen Organisasional?; Lebih besar mana pengaruh secara langsung Kepuasan Kerja terhadap Organizational Citizenship Behaviour melalui Komitmen Organisasional dengan pengaruh tidak langsung Kepuasan Kerja terhadap Organizational Citizenship Behaviour melalui Komitmen Organisasional? 
Sumijan

\section{Landasan Teori dan Pengembangan Hipotesis}

\section{Keadilan Prosedural Terhadap Komitmen Organisasional}

Komitmen karyawan terhadap organisasi dipengaruhi oleh beberapa faktor. Faktor tersebut bersumber oleh persepsi masing-masing karyawan yang berasal dari proses atasan dalam mengevaluasi kinerja bawahannya (Sani, 2013). Tambahan lain, menurut Rezaiean et al (2010) bahwa persepsi seorang karyawan diperoleh atas dasar penilaian mereka mengenai tata cara dan aturan yang diterapkan baik oleh pihak atasan. Apabila suatu prosedur atau aturan yang ditetapkan sudah dilaksanakan dengan baik oleh perusahaan melalui kebijaksanaan dan kebijakan prosedur perusahaan maka karyawan akan merasakan keadilan yang lebih baik dari perusahaan tersebut (Latan, 2014). Wang et al (2010) menyebutkan bahwa apabila keadilan yang didasarkan atas persepsi karyawan untuk melaksanakan prosedur yang ada pada perusahaan tersebuy maka disebutkan sebagai keadilan prosedural (Wang et al, 2010). Selanjutnya jika seorang karyawan mempunyai komitmen organisasi yang tinggi karena tingginya rasa keadilan prosedural maka karyawan akan merasakan puas terhadap pekerjaannya tersebut. Rasa puas karyawan yang muncul digambarkan sebagai perasaan senang atau tidak senang dalam menjalankan tugas-tugas yang menjadi beban kerjanya (Wang et al, 2010). Hasil studi yang dilakukan Hameed dan Waheed (2011) menunjukkan hasil studi bahwa keadilan prosedural mempunyai pengaruh secara signifikan terhadap komitmen.Menurut Moynihan et al (2010), bahwa apabila suatu pekerjaan yang dilakukan karyawan akan diatur pada suatu mekanisme, aturan atau prosedur yang sedemikian jelas dan terarah dalam kemungkinan terjadinya besar maka hal ini akan berdampak positif pada hasil kerja yang telah dilakukan seorang karyawan. Hal ini berarti apabila semakin baik tingkat keadilan prosedural yang diterapkan dalam sebuah perusahaan maka akan semakin baik tingkat produktivitas karyawan dan semakin baik juga komitmen karyawan terhadap organisasi (Khan et al, 2010)

$\mathrm{H}_{1}$ : Terdapat pengaruh yang signifikan antara Keadilan Prosedural Terhadap Komitmen Organisasional

\section{Kepuasan Kerja Terhadap Komitmen Organisasional}

Tujuan perusahaan akan tercapai apabila karyawan memiliki komitmen yang tinggi terhadap perusahaan (Aslam \& Sadaqat, 2010). Lok \& Crawford (2004) mendefinisikan komitmen organisasional sebagai ukuran dari kekuatan identitas dan keterlibatan karyawan dalam tujuan dan nilai-nilai organisasi. Dengan komitmen dan kontribusi yang diberikan dari karyawan terhadap organisasi, karyawan akan mendapatkan reward / imbalan yang sesuai (Sinclair et al, 2005), sebagaimana Luthans (2006) mendefinisikan komitmen organisasional sebagai sebuah sikap yang merefleksikan loyalitas karyawan kepada organisasi dan merupakan suatu proses berkelanjutan di mana anggota organisasi mengungkapkan perhatian mereka terhadap organisasi.

Hasil studi yang dilakukan Ueda (2009) bahwa kepuasan kerja akan berdampak positif yang signifikan terhadap komitmen organisasional. Hal ini disebutkan Ueda bahwa semakin baik tingkat kepuasan kerja yang dirasakan oleh karyawan maka akan semakin baik pula tingkat komitmen organisasional, dengan demikian sebaliknya apabila suatu karyawan merasa tidak puas maka menurunya rasa komitmen karyawan terhadap perusahaannya (Buentello et al, 2010). 
Sumijan

\section{$\mathrm{H}_{2}$ : Terdapat pengaruh yang signifikan antara Kepuasan Kerja Terhadap Komitmen Organisasional}

\section{Keadilan Prosedural Terhadap Organizational Citizenship Behaviour}

Kondisi keadilan prosedural dapat terpenuhi dengan tercapainya sebuah aturan, nilai atau norma yang ada seperti proses kendali prosedur dan keputusan, bias suppression, adanya tingkat akurasi, correctability, representatif dan bisnis berbasis etika (Sjahruddin et al, 2013). Konsep keadilan prosedural menurut Rezaiean et al bahwa seseorang tidak hanya melakukan penilaian terhadap suatu proses, aturan atau mekanisme atas munculnya penempatan atau sebaran hasil capaian (Rezaiean et al, 2010). Kemudian keadilan prosedural akan memiliki efek langsung pada suatu sikap dan perilaku karyawan dan akan berdampak berbanding terbalik pada perilaku negatif karyawan dalam organisasi (Ince dan Gul, 2011; Sjahruddin et al, 2013).

Sedangkan perilaku menyimpang (OCB) diartikan sebagai perilaku karyawan yang mencerminkan wujud loyalitasnya terhadap organisasi sehingga apa yang dilakukan akan membawa dampak pada meningkatkan efektivitas organisasi (Alameh et al, 2011). OCB ini dapat diposisikan atau didefinisikan sebagai peran utama (kewajiban) atau sebagai peran tambahan (bukan suatu kewajiban). Sedangkan sebagai penyelia maupun sebagai bawahan membutuhkan perhatian dari atasan langsung, khususnya yang berkaitan dengan alokasi prosedural (bagian dari organisasi dalam pengambilan keputusan) (Hepper dan Taylor, 2003). Menurut Hepper dan Taylor (2003) disebutkan jika perlakuan penyatuan kerangka kerja yang ada akan memberikan dampak terhadap keadilan procedural seorang atasan dalam sebuah hubungan sebab akibat yang mengarah pada OCB seorang bawahan sebagaimana disebutkan

$\mathrm{H}_{3}$ : Terdapat pengaruh yang signifikan antara Keadilan Prosedural Terhadap Organizational Citizenship Behaviour

\section{Kepuasan Kerja Terhadap Organizational Citizenship Behaviour}

Kepuasan kerja merupakan salah satu komponen yang mendukung tercapainya produktivitas. Menurut Susanty dan Miradipta (2013). Studi Ince dan Gul berpendapat apabila kepuasan kerja yang merujuk pada sikap umum seseorang individu terhadap pekerjaannya dengan tingkat kepuasan kerja yang baik maka akan ditunjukkan pada sikap positif akan pekerjaan tersebut. Sehingga apabila seseorang yang tidak puas dengan pekerjaan tersebut maka akan menunjukkan sikap yang negatif terhadap pekerjaan tersebut (Ince dan Gul, 2011).

Organizational Citizenship Behavior dapat muncul dari berbagai faktor dalam organisasi tersebut di antaranya adalah karena adanya kepuasan kerja dari karyawan dan komitmen organisasi yang tinggi (Greenberg \& Baron, 2008). Ketika karyawan merasakan kepuasan terhadap pekerjaan yang dilakukannya, maka seorang karyawan tersebut akan bekerja secara maksimal dalam menyelesaikan pekerjaannya (Chegini, 2009), bahkan melakukan beberapa hal yang mungkin diluar tugasnya (Ahmadi et al, 2011). Begitu juga dengan ketika seseorang mempunyai komitmen yang tinggi terhadap organisasi, maka orang tersebut akan melakukan apapun untuk memajukan perusahaannya karena keyakinannya terhadap organisasi (Gautam et al, 2000).

$\mathrm{H}_{4}$ : Terdapat pengaruh yang signifikan antara Kepuasan Kerja Terhadap Organizational Citizenship Behaviour 
Sumijan

\section{Komitmen Organisasional Terhadap Organizational Citizenship Behaviour}

Sani pada tahun 2011 berpendapat bahwa OCB merupakan komponen penting suatu organisasi yang disebabkan oleh perilaku untuk mendukung gerak mesin sosial perusahaan. OCB akan memberikan fleksibilitas yang diinginkan dan dibutuhkan sebuah organisasi untuk menyelesaikan pekerjaannya melalui keinginan-keinginan yang tidak direncanakan (Gayathiri dan Lalitha, 2013). Perilaku ini memungkinkan seluruh karyawan untuk mengatasi masalah-masalah yang ada oleh kondisi-kondisi yang mengharuskan pekerja bergantung satu sama lain (Sjahruddin, 2013). Kepuasan kerja yang baik akan menciptakan motivasi dan komitmen organisasional, sehingga akan memungkinkan tingginya perilaku OCB (Susanty dan Miradipta, 2013).

OCB dapat timbul dari berbagai faktor, faktor tersebut di antaranya adalah komitmen organisasional (Wong et al, 2004). Komitmen tersebut yang menjadi penggerak untuk terciptanya OCB guna tercapainya produktivitas dan kinerja perusahaan (Alameh et al, 2011). Seorang karyawan yang memiliki komitmen organisasional yang tinggi akan berusaha mencapai pengembangan diri guna tercapainya pula kemajuan organisasi (Dunlop dan Lee, 2004). Sedangkan karyawan yang tidak punya komitmen terhadap organisasi adalah karyawan yang cenderung tidak peduli dengan tujuan organisasi, sering melanggar aturan, dan kehilangan semangat bekerja. Sikap-sikap seperti itulah yang akhirnya akan berdampak pada kinerjanya. Hal tersebut sangat berdampak baik bagi perusahaan yang akhirnya dapat kembali bersaing secara kompetitif di dalam mendapatkan pangsa pasar dan juga akan berdampak untuk menghasilkan keuntungan yang jauh lebih besar (Rezaiean et al, 2010).

$\mathrm{H}_{5}$ : Terdapat pengaruh yang signifikan antara Komitmen Organisasional Terhadap Organizational Citizenship Behaviour

OCB memberikan dampak yang baik bagi sikap karyawan. Apabila karyawan merasa bahwa organisasi sebagai tempat setiap karyawan untuk diperlakukan secara baik dari keramahan yang ia terima dan adanya perasaan saling menghargai (Hameed dan Waheed, 2011). Hal tersebut menjadikan suatu organisasi sebagai tempat yang nyaman dan menyenangkan untuk bekerja bagi karyawan yang kemudian akan mendorong loyalitas atau rasa setia karyawan serta komitmen terhadap organisasi tersebut (Ismail et al, 2011). Terciptanya suasana yang baik yang dipengaruhi oleh OCB (Sani, 2013) maka karyawan akan merasa terdorong serta untuk bersemangat dalam menjalankan tugas serta tanggung jawabnya sehingga hasil dari pekerjaan tersebut akan menjadi lebih baik dan akan semakin berkualitas (Podsakoff et al, 1997).

$\mathrm{H}_{6}$ : Pengaruh secara langsung Keadilan Prosedural terhadap $O C B$ melalui Komitmen Organisasional memiliki pengaruh lebih besar daripada pengaruh tidak langsung Keadilan Prosedural terhadap $O C B$ melalui Komitmen Organisasional

$\mathrm{H}_{7}$ : Pengaruh secara langsung Kepuasan Kerja terhadap $O C B$ melalui Komitmen Organisasional memiliki pengaruh lebih besar daripada pengaruh tidak langsung Kepuasan Kerja terhadap $O C B$ melalui Komitmen Organisasional 


\section{Sumijan}

\section{Keadilan Prosedural $\left(\mathrm{X}_{\mathbf{1}}\right)$}

-Karakteristik tugas

-Tingkat kepercayaan bawahan terhadap supervisor

-Frekuensi feedback dalam proses komunikasi

- Kinerja manajerial

-Budaya organisasi

(Mc Farlin \& Sweeny, 1992)

L

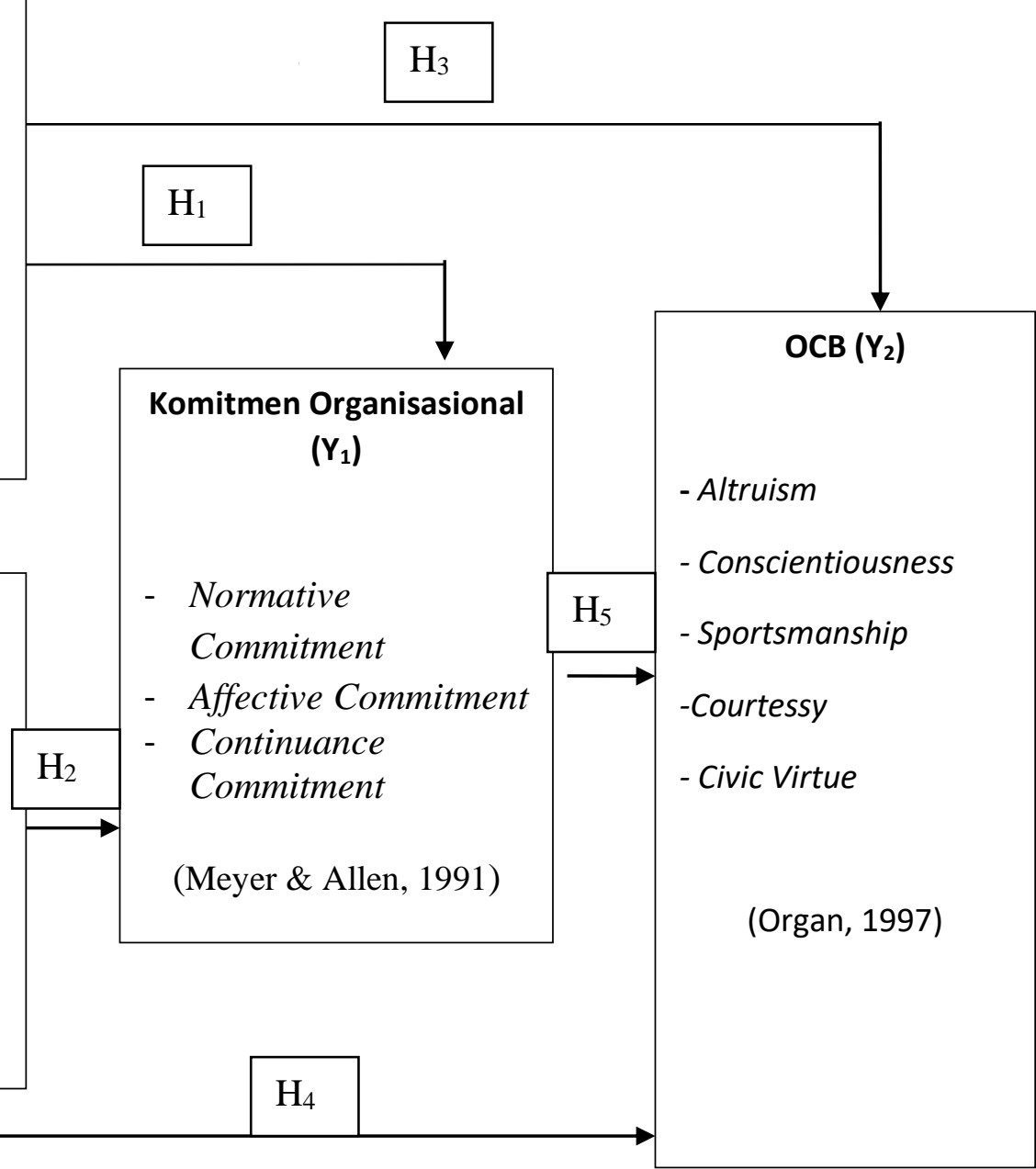

Gambar 1. Kerangka Pemikiran

\section{Metode Penelitian}

Dalam penelitian ini yang akan menjadi sampel penelitian adalah populasi dari seluruh karyawan PT Patrari Jaya Utama, maka teknik yang digunakan dalam penelitian ini adalah Sensus. Total seluruh karyawan PT Patrari Jaya Utama sebanyak 65 karyawan, sehingga sampel penelitian ini sebanyak 65 karyawan. Alat analisis yang digunakan adalah Analisis Regresi Linier Berganda serta analisis jalur (Path Analysis). variabel dalam penelitian ini yang digunakan antara lain:

\section{Keadilan Prosedural $\left(\mathbf{X}_{1}\right)$}

Variabel Keadilan prosedural menurut Mc Farlin dan Sweeny (1992) merupakan kondisi sudut pandang seorang karyawan akan penilaian suatu kewajaran, penilaian proses penghargaan dan keputusan mengenai aturan yang ditentukan suatu perusahaan yang sifatnya penting dan mengikat seperti keharusan membayar kompensasi 


\section{Sumijan}

berupa imbalan atau insentif, monitoring, promosi jenjang karir dan tindakan disiplin karyawan. Persepsi yang baik akan tingkat keadilan prosedural menghasilkan luaran perusahaan yang akan lebih baik seperti adanya perubahan secara positif atas komitmen karyawan terhadap organisasi, keinginan karyawan untuk tetap tinggal pada perusahaan serta peningkatan kinerja yang berkelanjutan. Variabel keadilan prosedural diukur dengan beberapa parameter, antara lain sebagai berikut: (Mc Farlin dan Sweeny, 1992)

a. Keakuratan informasi yang digunakan untuk dasar pengambilan keputusan

b. Pertimbangan usulan karyawan oleh atasan

c. Peraturan ditetapkan secara adil dan konsisten oleh perusahaan

d. Perusahaan menghargai semua karyawan tanpa adanya perbedaan

e. Karyawan melaksanakan pekerjaan sesuai dengan tata cara yang dirumuskan perusahaan

\section{Kepuasan Kerja $\left(\mathbf{X}_{2}\right)$}

Kepuasan kerja merupakan suatu perasaan akan bangga yang timbul dari dalam diri seseorang yang disebabkan karena terciptanya keuntungan lebih yang berada diluar ekspektasi sehingga mendatangkan perasaan senang akan hal tersebut. Menurut Robbins (2009) Kepuasan kerja (job satisfaction) mengacu kepada sikap individu secara umum terhadap pekerjaannya.Untuk mengetahui tingkat kepuasan kerja seseorang menggunakan indikator kepuasan kerja menurut Robbins (2009) antara lain:

a. Tingkat kesempatan untuk menggunakan kemampuan yang dimiliki untuk menyelesaikan pekerjaan tinggi

b. Tingkat kesempatan untuk mencapai prestasi yang didapatkan dari hasil pekerjaan tinggi

c. Tingkat kesempatan untuk hubungan interaksi dengan sesama rekan kerja baik

d. Tingkat kesempatan atas kondisi lingkungan kerja sangat kondusif, seperti ketersedian ruangan dan peralatan kerja dari perusahaan.

e. Tingkat kesesuaian dengan kompetensi

f. Tingkat kemudahan pekerjaan

g. Tingkat kesesuaian pengawasan kerja

\section{Komitmen Organisasional $\left(\mathbf{Y}_{1}\right)$}

Komitmen organisasional adalah sikap yang dimiliki karyawan untuk tetap loyal terhadap perusahaan dan bersedia untuk tetap bekerja dengan sebaik mungkin (Meyer \& Allen, 1991). Meyer \& Allen (1991) mengemukakan indikator komitmen organisasional, yaitu :

a. Kesenangan berkarier sepanjang hidup dalam organisasi.

b. Tingkat empati terhadap masalah setiap karyawan.

c. Perasaan memiliki terhadap organisasi.

d. Kebanggaan menjadi bagian dari keluarga organisasi.

e. Bekerja keras demi kepentingan organisasi

\section{Organizational Citizenship Behaviour (OCB) $\left(\mathrm{Y}_{2}\right)$}

OCB adalah perilaku karyawan yang dilakukan secara sukarela dan melebihi tuntutan pekerjaannya (Organ, 1997). Pengukuran variabel OCB diukur menggunakan indikator OCB dari Organ (1997) yang terdiri dari: 


\section{Sumijan}

a. Menolong rekan kerjanya yang mengalami kesulitan dalam situasi yang sedang dihadapi baik mengenai tugas dalam organisasi maupun masalah pribadi orang lain.

b. Berusaha melebihi yang diharapkan perusahaan.

c. Perilaku yang memberikan toleransi terhadap keadaan yang kurang ideal dalam organisasi tanpa mengajukan keberatan - keberatan.

d. Menjaga hubungan baik dengan rekan kerjanya agar terhindar dari masalah - masalah interpersonal.

e. Tanggung jawab yang diberikan organisasi kepada seorang untuk meningkatkan kualitas bidang pekerjaan yang ditekuni.

\section{Pembahasan}

1. Pengujian normalitas data

Hasil uji normalitas data dengan menggunakan One-Sample Kolmogorov-Smirnov Test adalah sebagai berikut:

Tabel 1. Uji Normalitas

\begin{tabular}{|l|r|r|r|r|}
\hline & \multicolumn{1}{|c|}{$\mathrm{TX}_{1}$} & \multicolumn{1}{c|}{$\mathrm{TX}_{2}$} & \multicolumn{1}{c|}{$\mathrm{TY}_{1}$} & \multicolumn{1}{c|}{$\mathrm{TY}_{2}$} \\
\hline N (Jumlah Sampel) & 65 & 65 & 65 & 65 \\
\hline Kolmogorov-Smirnov Z & 1.318 & 1.218 & 1.103 & .941 \\
\hline Asymp. Sig. (2-tailed) & .062 & .084 & .087 & .339 \\
\hline
\end{tabular}

Sumber: Data diolah

Berdasarkan uji One Sampel Kolmogorov Smirnov didapatkan nilai probabilitas signifikan lebih besar dari $5 \%$. Hal ini berarti bahwa seluruh variabel penelitian memiliki sebaran data yang normal.

2. Pengujian Multikolinearitas

Hasil uji multikolinearitas disajikan pada tabel berikut:

Tabel 2. Uji Multikolinearitas

\begin{tabular}{|l|r|r|c|}
\hline \multicolumn{1}{|c|}{ Variabel Penelitian } & $\begin{array}{c}\text { Nilai } \\
\text { Tolerance }\end{array}$ & $\begin{array}{c}\text { Nilai VIF (Varians } \\
\text { Inflation Factor) }\end{array}$ & Keputusan \\
\hline Keadilan Prosedural $\left(\mathrm{X}_{1}\right)$ & 0.378 & 2.642 & $\begin{array}{c}\text { Tidak Terjadi } \\
\text { Multikolinearitas }\end{array}$ \\
\hline Kepuasan Kerja $\left(\mathrm{X}_{2}\right)$ & 0.310 & 3.230 & $\begin{array}{c}\text { Tidak Terjadi } \\
\text { Multikolinearitas }\end{array}$ \\
\hline $\begin{array}{l}\text { Komitmen Organisasional } \\
\left(\mathrm{Y}_{1}\right)\end{array}$ & 0.301 & 3.327 & $\begin{array}{c}\text { Tidak Terjadi } \\
\text { Multikolinearitas }\end{array}$ \\
\hline
\end{tabular}

Sumber : Data diolah

3. Pengujian Heterokedastisitas

Hasil uji Heterokedastisitas disajikan pada Tabel berikut: 
Sumijan

Tabel 3. Uji Heterokedastisitas

\begin{tabular}{|l|c|c|c|}
\hline \multicolumn{1}{|c|}{ Variabel Penelitian } & $\begin{array}{c}\text { Koefisien } \\
\text { Korelasi } \\
\text { Spearman }\end{array}$ & Signifikansi & Keputusan \\
\hline Keadilan Prosedural $\left(\mathrm{X}_{1}\right)$ & 0.013 & 0.915 & $\begin{array}{c}\text { Tidak Terjadi } \\
\text { Heterokedastisitas }\end{array}$ \\
\hline Kepuasan Kerja $\left(\mathrm{X}_{2}\right)$ & 0.033 & 0.792 & $\begin{array}{c}\text { Tidak Terjadi } \\
\text { Heterokedastisitas }\end{array}$ \\
\hline $\begin{array}{l}\text { Komitmen } \\
\text { Organisasional }\left(\mathrm{Y}_{1}\right)\end{array}$ & 0.102 & 0.419 & $\begin{array}{c}\text { Tidak Terjadi } \\
\text { Heterokedastisitas }\end{array}$ \\
\hline
\end{tabular}

Sumber : Data diolah

\section{Analisis jalur (Path Analysis)}

Analisis jalur terdiri atas dua bentuk persamaan struktural, di mana $\mathrm{X}_{1}, \mathrm{X}_{2}$ adalah variabel bebas penelitian sedangkan $\mathrm{Y}_{1}$ dan $\mathrm{Y}_{2}$ adalah variabel terikat penelitian. Selanjutnya analisis jalur dengan menggunakan bantuan SPSS terdiri dari dua langkah pengujian. Yang pertama adalah analisis untuk model 1 dan kedua adalah model 2. Pada tahap ini juga terdapat penafsiran interpretasi hasil. Pada tahapan ini dibedakan tiga analisis, yaitu analisis regresi linear berganda, analisis korelasi dan penghitungan pengaruh variabel. Analisis regresi linear berganda melihat uji pengaruh secara gabungan dan melihat pengaruh secara parsial atau sebagian. Sedangkan, analisis korelasi pada persamaan model pertama dengan melihat analisis korelasi antar variabel dan persamaan model kedua dengan melihat analisis korelasi antar variabel penelitian. Tabel di bawah ini memberikan informasi ringkas perhitungan mengenai koefisien (efek) dari pengaruh total variabel-variabel penelitian yaitu Keadilan Prosedural $\left(\mathrm{X}_{1}\right)$ dan Kepuasan Kerja $\left(\mathrm{X}_{2}\right)$ terhadap variabel OCB $\left(\mathrm{Y}_{2}\right)$ melalui variabel Komitmen Organisasional $\left(\mathrm{Y}_{1}\right)$.

Tabel 4. Hasil Analisis Jalur

\begin{tabular}{|c|c|c|c|c|c|}
\hline No & $\begin{array}{c}\text { Arah Pengaruh } \\
\text { Variabel }\end{array}$ & $\begin{array}{c}\text { Koefisien } \\
\text { Pengaruh } \\
\text { Langsung } \\
\text { Model }\end{array}$ & $\begin{array}{c}\text { Koefisien } \\
\text { Pengaruh } \\
\text { Tidak } \\
\text { langsung } \\
\text { Model }\end{array}$ & $\begin{array}{c}\text { Koefisien } \\
\text { Pengaruh } \\
\text { Total } \\
\text { Model }\end{array}$ & Keputusan \\
\hline 1 & $\mathrm{X} 1 \rightarrow \mathrm{Y} 1$ & .347 & - & - & Signifikan \\
\hline 2 & $\mathrm{X} 2 \rightarrow \mathrm{Y} 1$ & .545 & - & - & Signifikan \\
\hline 3 & $\mathrm{X} 1 \rightarrow \mathrm{Y} 2$ & .471 & - & - & Signifikan \\
\hline 4 & $\mathrm{X} 2 \rightarrow \mathrm{Y} 2$ & .126 & - & - & $\begin{array}{c}\text { Tidak } \\
\text { Signifikan }\end{array}$ \\
\hline 5 & $\mathrm{Y} 1 \rightarrow \mathrm{Y} 2$ & .278 & - & - & Signifikan \\
\hline 6 & $\mathrm{X} 1 \rightarrow \mathrm{Y} 1 \rightarrow \mathrm{Y} 2$ & - & .096 & .567 & Signifikan \\
\hline 7 & $\mathrm{X} 2 \rightarrow \mathrm{Y} 1 \rightarrow \mathrm{Y} 2$ & - & .151 & .277 & Signifikan \\
\hline
\end{tabular}

Sumber: Data diolah

Lintasan pengaruh antar variabel digambarkan sebagai berikut : 


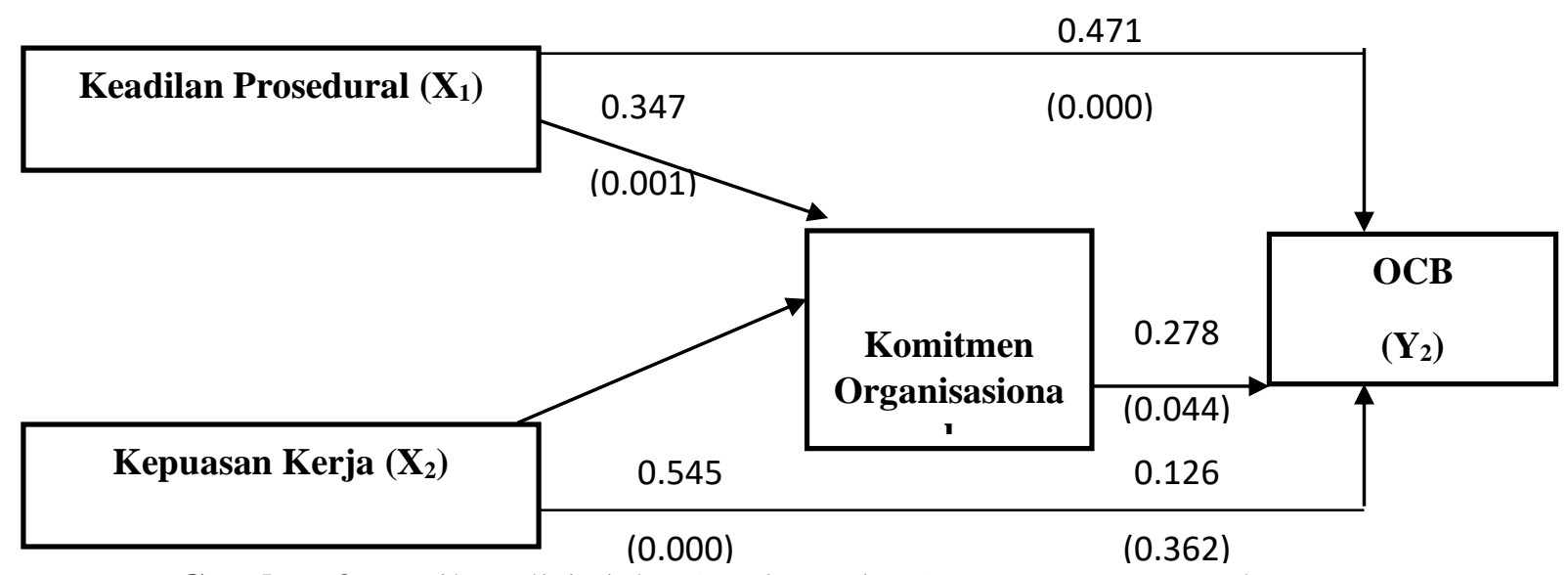

Gambar 2. Hasil analisis jalur (Path Analysis) antara $\mathrm{X}_{1}, \mathrm{X}_{2}, \mathrm{Y}_{1}$ dan $\mathrm{Y}_{2}$

Sumber: Data diolah

Hasil penelitian disimpulkan bahwa ada pengaruh yang signifikan antara keadilan prosedural dengan komitmen organisasional dengan nilai signifikansi $t$ statistic sebesar 0.001 . Komitmen karyawan terhadap organisasi dipengaruhi oleh beberapa faktor. Faktor tersebut bersumber oleh persepsi masing-masing karyawan yang berasal dari proses atasan dalam mengevaluasi kinerja bawahannya (Sani, 2013). Tambahan lain disebutkan bahwa persepsi karyawan didapatkan atas dasar penilaian mereka terhadap prosedur yang diterapkan oleh atasan (Rezaiean et al, 2010). Jika prosedur atau aturan yang ditetapkan sudah dilaksanakan dengan baik oleh perusahaan melalui kebijaksanaan maka karyawan akan memperoleh rasa keadilan yang baik dari perusahaan (Latan, 2014).

Hasil penelitian disimpulkan bahwa ada pengaruh yang signifikan antara Kepuasan Kerja dengan Komitmen Organisasional dengan nilai signifikansi $t$ statistic sebesar 0.000 . Tujuan perusahaan akan tercapai apabila karyawan memiliki komitmen yang tinggi terhadap perusahaan (Aslam \& Sadaqat, 2010). Lok \& Crawford (2004) mendefinisikan komitmen organisasional sebagai ukuran dari kekuatan identitas dan keterlibatan karyawan dalam tujuan dan nilai-nilai organisasi. Dengan komitmen dan kontribusi yang diberikan dari karyawan terhadap organisasi, karyawan akan mendapatkan reward / imbalan yang sesuai (Sinclair et al, 2005), sebagaimana Luthans (2006) mendefinisikan komitmen organisasional sebagai sebuah sikap yang merefleksikan loyalitas karyawan kepada organisasi dan merupakan suatu proses berkelanjutan di mana anggota organisasi mengungkapkan perhatian mereka terhadap organisasi (Yun et al, 2007). Hasil studi Ueda (2009) bahwa kepuasan kerja memiliki dampak yang positif dan signifikan terhadap komitmen organisasional (Ueda, 2009). Hal ini berarti semakin semakin baik tingkat kepuasan kerja yang dirasakan oleh karyawan maka akan semakin baik pula tingkat komitmen organisasionalnya, demikian sebaliknya jika suatu karyawan merasa tidak puas maka akan turun rasa komitmen mereka terhadap perusahaannya (Buentello et al, 2010). Kepuasan kerja yang diparameterkan oleh beban kerja, besaran gaji, serta kenaikan jabatan, pengawas dan rekan kerja akan menunjukkan telah dikelola secara baik sehingga akan memberikan dampak terhadap komitmen organisasional (Mohammad et al, 2011).

Hasil penelitian dapat disimpulkan bahwa ada pengaruh yang signifikan antara keadilan prosedural dengan Organizational Citizenship Behaviour dengan nilai signifikansi $t$ statistic sebesar 0.000. Kondisi keadilan prosedural dapat dicapai dengan memenuhi sebuah aturan atau norma yang ada seperti proses kendali, keputusan, bias supression, tingkat akurasi, correctability, representatif dan berbasis etika (Sjahruddin et al, 2013). Konsep keadilan prosedural menurut Rezaiean et al bahwa seseorang tidak hanya dapat melakukan 


\section{Sumijan}

penilaian terhadap proses atau mekanisme munculnya penempatan dan distribusi hasil capaian (Rezaiean et al, 2010). Kemudian keadilan prosedural memiliki dampak searah pada sikap dan perilaku karyawan dan sebaliknya akan berdampak berbanding terbalik pada perilaku negatif atau perilaku menyimpang dalam organisasi (Ince dan Gul, 2011; Sjahruddin et al, 2013). Sedangkan perilaku menyimpang (OCB) diartikan sebagai perilaku karyawan yang mencerminkan wujud loyalitasnya terhadap organisasi sehingga apa yang dilakukan akan membawa dampak pada meningkatkan efektivitas organisasi (Alameh et al, 2011). OCB ini dapat diposisikan atau didefinisikan sebagai peran utama (kewajiban) atau sebagai peran tambahan (bukan suatu kewajiban). Sedangkan sebagai penyelia maupun sebagai bawahan membutuhkan perhatian dari atasan langsung, khususnya yang berkaitan dengan alokasi prosedural (bagian dari organisasi dalam pengambilan keputusan) (Hepper dan Taylor, 2003).

Hasil penelitian disimpulkan bahwa tidak terdapat pengaruh antara kepuasan kerja terhadap Organizational Citizenship Behaviour dengan nilai signifikansi $t$ statistic sebesar 0.362. Kepuasan kerja seharusnya menjadi salah satu komponen yang mendukung tercapainya produktivitas. Menurut Susanty dan Miradipta (2013), Kepuasan kerja merujuk pada sikap umum seseorang individu terhadap pekerjaannya. Seseorang dengan tingkat kepuasan kerja tinggi menunjukkan sikap yang positif terhadap pekerjaan itu. Seseorang tidak puas dengan pekerjaannya menunjukkan sikap yang negatif terhadap pekerjaan itu (Ince dan Gul, 2011). Ketika karyawan merasakan kepuasan terhadap pekerjaan yang dilakukannya, maka karyawan tersebut akan bekerja secara maksimal dalam menyelesaikan pekerjaannya (Chegini, 2009), bahkan melakukan beberapa hal yang mungkin diluar tugasnya (Ahmadi et $a l$, 2011). Begitu juga dengan ketika seseorang mempunyai komitmen yang tinggi terhadap organisasinya, maka orang tersebut akan melakukan apapun untuk memajukan perusahaannya karena keyakinannya terhadap organisasinya (Gautam et al, 2000).

Hasil penelitian disimpulkan bahwa ada pengaruh yang signifikan antara Komitmen Organisasional dengan Organizational Citizenship Behaviour dengan nilai signifikansi $t$ statistic sebesar 0.044. Sani pada tahun 2011 berpendapat bahwa Organizational Citizenship Behavior (OCB) menjadi sebuah komponen penting pada suatu organisasi dikarenakan perilaku tersebut akan mendukung gerak mesin sosial. OCB akan memberikan fleksibilitas yang diinginkan dan dibutuhkan sebuah organisasi untuk menyelesaikan pekerjaannya melalui keinginan-keinginan yang tidak direncanakan (Gayathiri dan Lalitha, 2013). Perilaku ini memungkinkan anggota karyawan untuk mengatasi masalah yang ada untuk dapat ditimbulkan oleh kondisi-kondisi yang mengharuskan pekerja bergantung satu sama lain (Sjahruddin, 2013). Kepuasan kerja yang baik akan menciptakan motivasi dan komitmen organisasional yang tinggi pula, sehingga akan memungkinkan munculnya perilaku OCB yang positif (Susanty dan Miradipta, 2013).

Hasil penelitian menunjukkan bahwa besarnya pengaruh tidak langsung keadilan prosedural terhadap Organizational Citizenship Behavior melalui komitmen organisasional karyawan sebesar 0.096, sedangkan besarnya pengaruh total keadilan prosedural terhadap Organizational Citizenship Behavior melalui komitmen organisasional adalah sebesar 0.567. Hasil penelitian menunjukkan bahwa besarnya pengaruh tidak langsung kepuasan kerja terhadap Organizational Citizenship Behavior melalui komitmen organisasional karyawan sebesar 0.151, sedangkan besarnya pengaruh total kepuasan kerja terhadap Organizational Citizenship Behavior melalui komitmen organisasional adalah sebesar 0.277.

\section{Kesimpulan}

Hasil penelitian menunjukkan bahwa terdapat pengaruh yang signifikan antara Keadilan Prosedural terhadap Komitmen Organisasional; Terdapat pengaruh yang signifikan antara 


\section{Sumijan}

Kepuasan Kerja terhadap Komitmen Organisasional; Terdapat pengaruh yang signifikan antara Keadilan Prosedural terhadap Organizational Citizenship Behaviour; Tidak terdapat pengaruh antara Kepuasan kerja terhadap Organizational Citizenship Behaviour; Terdapat pengaruh yang signifikan antara Komitmen Organisasional terhadap Organizational Citizenship Behaviour.

Pada level atasan perlu pemahaman konsep mengenai prosedur dan sistem kerja serta memahami situasi antara atasan dan bawahan atau manajer dan karyawan, secara formal atau informal, harus memperhatikan keselarasannya agar tetap menjaga pada level keadilan. Pihak atasan harus mampu mempersepsikan semua karyawan adalah sebuah mitra perusahaan dan mereka sama pentingnya untuk memajukan perusahaan.

Peneliti lain yang tertarik pada bidang Sumber Daya Manusia terutama terkait upaya peningkatan sikap komitmen karyawan serta perilaku karyawan maka penelitian ini dapat dijadikan sebagai bahan dan sumber inspirasi untuk melakukan penelitian lanjutan. Bagi penelitian selanjutnya disarankan dapat mempertimbangkan beberapa hal, antara lain: penelitian lanjutan diharapkan dapat menambah variabel penelitian serta mengganti parameter yang menjadi dugaan faktor yang dapat memengaruhi atau dipengaruhi variabel penelitian; membandingkan beberapa unit analisis penelitian, misalnya adanya penambahan instansi pemerintahan kesehatan, nirlaba atau lembaga pendidikan untuk mendapatkan hasil yang berbeda dan menjadi kebaharuan penelitian selanjutnya

\section{DaftarPustaka}

Ahmadi, Freyedon. Seyed Ali Akbar., dan Tavreh Naser. (2011). "Survei Relationship Between Organizational Justice and Organizational Citizenship Behavior (OCB) of Food Product Firms in Kurdestan Province". Interdisciplinary Journal of Contemporary Research in Business. 2(10)

Allameh, Sayyed Mohsen., Samane Amiri., dan Ali Asadi. (2011). A Survei of Relationship Between Organizational Commitments and Organizational Citizenship Behavior Case Study : Regional Water Organization of Mazandaran Province". Interdisciplinary Journal of Contemporary Research in Business. 3 (5)

Alotaibi, A. G. (2001). Antacedents of Organizational Citizenship Behavior: A Study of Public Personnel in Kuwait. Journal Public Personnel Management. 30 (3)

Aslam, Rabia., and Sadaqat, Shama. (2011) Investigating the Relationship of Organizational Justice on Organizational Citizenship Behavior among Teacing Staff of University of the Punjab". European Journal of Scientific Research, 57(1)

Buentello, Giap, Binh Nga., Hackermeier, Irish., Jiao Xueli.,\& Wagdarikar, Sakina Pramon. (2010). Organizational Citizenship Behavior and Perception of Organizational Justice in Student Jobs. Pschology of Excellence Ludwig

Chegini, Mehrdad Goudarzvand., (2009) "The Relationship between Organizational Justice and Organizational Citizenship Behavior", American Journal of Economics and Business Administration, 1(2)

Cropanzano, R., dan Greenberg, J., (1997) "Progress in Organizational Juctice: Tunneling Through the Maze”. In C. L. Cooper,. dan I. T. Robertson (Eds.) International Review of Industrial and Organizational Psychology, 12, pp. 617-372, Chister:John Wiley \& Sons

Damayanti, Komi dan Fendy Suhariadi. 2003. Hubungan antara Persepsi terhadap Keadilan Organisasi dengan Komitmen Karyawan pada Organisasi di PT. Haji Ali Sejahtera, Insan Media Psikologi, Volume 5, No. 2, Agustus 2003, pp. 127-135 


\section{Sumijan}

Gautam, Zahra; Soltanahmadi, Javad Abdeli; Pashavi, Ghasem; Nekouei, Sedigheh. (2000). "Empowerment as a Basic Step in Upgrading Organizational Commitment and Organizational Citizenship Behaviors: A Case Study on Public Sector in Iran”. World Applied Sciences Journal 21 (11)

Gayathiri, R., dan Lalitha Ramakrishnan., (2013) "Quality of Work Life Linkage with Job Satisfaction and Performance", International Journal of Business and Management Invention, Vol. 2

Greenberg, J., dan Baron, R. A., (2003) Behavior In Organizations: Understanding and Managing The Human Side of Work, $8^{\text {th }}$ edition, New Jersey, Prentice Hall

Hameed, A., Waheed A. (2011). Employee Development and It's Affect on Employee Performance. International Journal of Business and Social Science. 2(13)

Hepper dan Taylor., (2003) "Organizational Justice and Turnover in Public Accountant Firms: a Research Note", Accounting, Organizations, and Society, 30

Ince, Mehmet., dan Hasan, Gul., (2011) "The Effect of Employees Perceptions of Organizational Justice on Organizational Citizenship Behavior: An Application in Turkish Public Institutions", International Journal of Business and Management, Vol. 6, No. 6

Ismail, Keeping, L.M. \& Levy, P.E. (2014). Performance Appraisal Reactions: Measurement, Modelling And Method Bias. Journal of Applied Psychology, 85(5)

Khan, Rashid., (2012) "The Mediating Effect of Organizational Commitment in the Organizational Culture, Leadership and Organizational Justice Relationship with Organizational Citizenship Behavior", A Study of Academicians in Private Higher Learning Institutions in Malaysia, Vol. 3, No. 8

Latan, (2014). Human behavior at Work: Organizational Behavior. Eighth edition. Mc. Graw Hill Book Company, Singapore

Lok \& Crawford., (2004) "The Relationship Between Affective and Continuance Organizational Commitment", Journal of Asian Business Strategy, Vol. 2, No. 5

Luthans, Fred., (2006), Organizational Behavior, $7^{\text {th }}$ edition, McGraw Hill

McFarlin, D., dan Sweeney, P., (1992) "Distributive and Procedural Justice as Predictors of Satisfaction with Personal and Organizational Outcomes", Academy of Management Journal, 35

Meyer, Jhon P., dan Natalie J. Allen., (1991) "A Three Component Conceptualization of Organizational Commitment", Human Resource Management Review, 1 (1)

Moormant, R., (1991) "Relationship Between Organizational Justice and Organizational Citizenship Behaviors: do Fairness Perceptions Influence Employee Citizenship?", Journal of Applied Psychology, 76

Moynihan, Manning, Michael R., dan Packard, John S. (2000). The Influence of Job Satisfaction and Organizational Commitment on Executive Withdrawal and Performance. Journal of Applied Psychology, Vol. 71, No. 4

Organ, Dennis W., (1997) Organizational Citizenship Behavior: It's Construct Clean-Up Time. Journal: Human Performance, 10 (2) 85-97

Podsakoff, P. M., Michael Ahearne., dan Scott B. MacKenzie., (1997), ”Organizational Citizenship Behavior and the Quantity and Quality of Work Group Performance", Journal of Applied Psychology, 82(2)

Rezaiean, A., Givi, M. E., and Nasrabadi, M. B., (2010) "The Relationship between Organizational Justice and Organizational Citizenship Behaviors: the Mediating Role 


\section{Sumijan}

of Organizational Commitment, Satisfaction and Trust", Research Journal of Business Management, 4(2)

Robbins, P., (2009), Perilaku Organisasi, Jakarta, Indeks

Sani, Achmad., (2013) "Role of Procedural Justice, Organizational Commitment and Job Satisfaction on job Performance: The Mediating Effects of Organizational Citizenship Behavior", International Journal of Business and Management, 8(15)

Scholl, Richard W. (1981). Differentiating Organization Commitment From Expectancy as a Motivating Force", Academy of Management Review, 1981, Volume 6, No. 4, 589599

Sinclair, A., (2005) "Approaches to Organizational Culture and Ethics", Journal of Business Ethics, Vol. 12

Sjahruddin, Herman., (2013) "Organizational Justice, Organizational Commitment and Trust in Manager as predictor of Organizational Citizenship Behavior", Interdisciplinary Journal of Contemporary Research in Business, 4(12)

Susanty, Aries dan Miradipta Rizqi (2013). Employee's Job Performance: The Effect of Attitude toward Works, Organizational Commitment, and Job Satisfaction. Jurnal Teknik Industri. Vol 15. No 1

Ueda,Yutaka. (2009). Organizational citizenship behavior in a Japanese organization: The effects of job involvement, organizational commitment, and Collectivism. Human Resource Management, 36 (6)

Wang, Yui-Tim, (2010) "Perceived Organizational Justice, Trust, and OCB: A Study of Chinese Workers in Joint Ventures and State-owned Enterprises", Academy of Management Journal. Vol 20

Widyaningrum, Mahmudah Enny. (2010). Pengaruh Keadilan Organisasi Terhadap Kepuasan Kerja, Komitmen Dan Organizational Citizenship Behavior Pegawai (Studi Kasus Di Rumah Sakit Bersalin Pura Raharja Surabaya) Tahun 2009. Majalah Ekonomi. Tahun XX, No. 1 April 2010

Wong, Qaisar, Muhammad Usman., Muhammad Safdar Rehman., dan Muhammad Suffyan. (2004). Perceived Organizational Justice, Trust, and OCB: A Study of Chinese Workers in Joint Ventures and State-owned Enterprises. Interdisciplinary Journal of Contemporary Research in Business, Vol. 3, No. 11 